\title{
Using Pooled Model, Random Model And Fixed Model Multiple Regression To Measure Foreign Direct Investment In Taiwan
}

Thomas Hiestand, (Email: hiestand@ cord.edu), Concordia College

\begin{abstract}
Through out the paper, two questions will be answered. The first question is, which are the countries that contribute largely to Taiwan FDI? The second question the paper is going to explore is what are the factors that draw FDI into Taiwan. According to the current literature on FDI in other countries, the determinants of FDI are relative market size, relative labor cost, distance and literacy rate. Three versions of the empirical model were estimated. They are Pooled regression model, Fixed Effect (FE) model, and Random Effect (RE) model. Throughout the three models, the relative market size hypothesis was consistently proved to be a key determinant of FDI in Taiwan.
\end{abstract}

\section{INTRODUCTION}

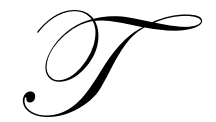

his paper analyzes the determinants of Foreign Direct Investment (FDI) in Taiwan. It would be appropriate at the outset of this paper to provide the definition of FDI, consider how FDI differs from Foreign Portfolio Investment (FPI) and some background information on FDI in Taiwan. The International Monetary Fund (IMF) defines FDI as "an investment that is made to acquire a lasting interest in an enterprise operating in an economy other than that of the investor, the investor's purpose being to have an effective voice in the management of the enterprise." In addition, the US Department of Commerce, defines FDI as "movement of long term capital to finance business activities abroad, whereby investors control at least $10 \%$ of the enterprise" (Poniachek, 1986)

Often, FPI is viewed to be in the same category as that of FDI. It is true that they are quite similar in a number of respects and characteristics such as they both provide a transfer of capital. However, Reuber and Crookell (1990) state that there are several major differences between those two investments. Firstly, portfolio investment flows tend to be 'industry specific'. Secondly, FPI does not directly affect local non-resident ownership and control, whereas FDI gives rise to non-resident ownership and control. Thirdly, portfolio investment normally implies a transfer of capital only, whereas FDI usually comprises a transfer of not only capital but also a package of auxiliary factors.

FDI has a long lasting interest in a country. Over the past decade, FDI has continued to grow at a dramatic rate. In contrast, FPI appears to have been reduced rather drastically in particular after every major financial crisis. This depicts the short lasting interest in a country for FPI. The institute of International Finance gave estimates on capital flows to emerging twenty-five markets, showing FDI values of $\$ 111$ billion in 1998 and $\$ 103.9$ billion in 1999; FPI values of $\$ 118.3$ billion in 1997, $\$ 50.7$ billion in 1998 and $\$ 44.3$ billion in 1999 . The aforementioned data above also seems to support the view that portfolio investment is more risky and volatile than FDI. Investors can quickly withdraw the portfolio investment funds from the host country. 
Foreign direct investment inflows into Taiwan had always been rising until year 2000, with the exception of 1998, when the Asian financial crisis took place. Between 1952 and 2000, $22.6 \%$ of FDI in Taiwan came from the United States, 20.3\% from Japan, 12\% from Europe and 2.3\% from Hong Kong. During the past four decades, just over 25\% (US $\$ 9.4$ billion) of FDI into Taiwan has been channeled into electronics and electrical sectors. The vast majority of this has arrived in the past decade, as Taiwan has become one of the world's largest producers of computer peripherals, semiconductors and other high technological products (Hong Ming-Yu, 2002). Given the fact that FDI inflows into Taiwan had been rising continuously, what is the reason behind that draws foreign direct investment into Taiwan?

\section{Issue Statement}

This paper seeks to identify: (1) the countries that contribute largely to Taiwan foreign direct investment and (2) the factors that draw foreign direct investment into Taiwan.

\section{Methodology}

Multiple regression model is being used in this paper to identify the major determinants of FDI in Taiwan. The behaviors of several relevant independent variables (which will be discussed later in Chapter II) are employed to explain the behavior of the dependent variable, which is FDI in Taiwan. Data collection is the first step of this methodology. The basic data set of the paper is outward FDI from the nine largest source countries in the 1983-1997 periods. The sample period begins in 1983 since FDI in Taiwan was not significant before 1983. The sample period ends in 1997 since Asian Financial Crisis occurred in that year which had significant impact on FDI that may distort the analysis. The second step of the methodology is to empirically test the variables and figure out which of the independent variables are related to the increase or decrease of the FDI in Taiwan.

\section{Limitations}

The determinants of FDI are often grouped into demand side and supply side factors. The demand side determinants include market size, labor cost, distance cost, literacy rate and political stability. And the supply side determinants consist of economies of scale, product life cycles, etc. This paper only discusses some of the demand side determinants of FDI, as the supply side factors and some less-quantifiable demand side factors are not easy to measure and constrained by the lack of availability of data.

\section{LITERATURE REVIEW}

\section{FDI In Taiwan}

The current decade is witnessing the growing significance of foreign investments in the world economy. During 1983 to 1987, the total yearly investment inflow for all countries averaged US\$77.1 billion. This figure has increased so dramatically that by 1995 investment inflow stood at US $\$ 314.9$ billion (Statistical Yearbook of Taiwan Province, 1996). FDI also plays an important role in helping to accelerate the process of economic development in the host country (Bende-Nabende and Ford, 1998). Back in 1952, FDI was not significant until the mid 1960 (Central Bank of China, 1981). Schive (1990) indicates that during the period 1952-1986, FDI by both Overseas Chinese and Non-Chinese, who arrive in Taiwan at an average rate of $16.73 \%$, reach a total of about \$350 million in 1986 .

The rise in FDI in Taiwan is not a unique experience when compared to her regional neighboring countries. Since 1986, the Asia-Pacific region has become the largest recipient of FDI among developing countries. In 1989, Japan was the largest investor in the ASEAN region. However, in 1990, investment by the Asian NIEs, which includes the Republic of Korea, Taiwan, Hong Kong, and Singapore, reached $\$ 3.73$ billion, a $33.8 \%$ share, exceeding Japan's investment of 2.88 billion, a $26.2 \%$ share (Leon, 1996). Being part of the member in the Asian NIEs, the government of the Republic of China of Taiwan has encouraged foreign industries to participate in the economic development of Taiwan. 
The ROC government's effort in promoting the active participation of foreign industries in Taiwanese economic development is a successful story (Chen, 1992). This is clearly indicated by the United Nations' ranking of the foreign investment absorption (FIA) of the host countries and territories with respect to FDI inflows between 1990 to 1996 , in which Taiwan was ranked the $28^{\text {th }}$ in the world. The annual average flow of FDI between this period has reached 1207 millions of dollars. It doubles the figures when compared to 691 millions of dollars in the period of 1984 to 1989.

Part of Taiwan's success in attracting FDI lies in her geographical position. Taiwan is a premier location for foreign firms to invest in. This island is located in the heart of the Asia-Pacific area that offers a great geographical convenience, advanced transportation system and communications facilities, modern infrastructure, skilled labor, and similar cultural ties with almost all of its neighbor countries. In addition, over the past forty years, the ROC government has been promoting FDI. The incentives embodied within the relevant statutes and regulations have been generous to attract large numbers of foreign investors, as well as helping to meet the developmental needs of the nation. This judicious mix of policies has enabled Taiwan to establish a reputation as a premier location for virtually any kind of international business or marketing.

The ultimate object of governments in attracting FDI is to promote growth, development and to provide jobs and to introduce needed industries and technology. Much has been written with regard to Taiwan's spectacular economic growth in the last decade, which has been partly attributed to FDI (Gereffie and Wyman, 1991). Taiwan thus presents an interesting case for our purpose of study on the determinants of foreign direct investment.

\section{Countries That Contribute Largely To Taiwan Foreign Direct Investment}

In 1952, there are only a few foreign-owned firms on Taiwan's soil. Almost all of the foreign direct investment comes from overseas Chinese only. The total amount of foreign direct investment was US $\$ 0.1$ million. Taiwan's FDI continued to increase at an increasing rate. The amount of foreign direct investment in 1985 and 1986 reached US\$0.7 and US\$0.8 million, respectively (Investment Commission M.O.E.A., 1992). By the end of 1997, the amount of FDI in Taiwan reached US\$4.2 billion with a remarkable growth rate of 173\% (Statistical yearbook of Taiwan Province, 1998).

Table 2.1 FDI From The Five Largest Sources Countries, 1983-1997 (US\$'000)

\begin{tabular}{|l|c|c|c|c|c|}
\hline & JA & NE & SI & US & HK \\
\hline Mean & 438760.7 & 57385.07 & 82552.67 & 380328.9 & 121983.4 \\
\hline SD & 225812.7 & 40922.2 & 115180.4 & 291363.2 & 69540.1 \\
\hline Max & 851139.0 & 159253.0 & 449976.0 & 1275623.0 & 232099.0 \\
\hline Min & 113978.0 & 3091.0 & 206.0 & 93294.0 & 13980.0 \\
\hline
\end{tabular}

Sources: Investment Commission M.O.E.A (1992)

The Distribution of FDI in terms of major source countries for 1985 to 1997 is summarized in Table 2.1. The five largest source countries of direct investment in Taiwan over these periods are: Japan, Netherlands, Singapore, United States, and Hong Kong. With reference to the pie chart in Figure 2.2, Japan and US are the dominant suppliers of FDI. Of the total US $\$ 18$ billion, Japan contributed US $\$ 5$ billion or $33 \%$ while the US contributed US $\$ 5$ billion or 27\% (Investment Commission M.O.E.A., 1992).

It is not a surprise that the largest contribution of FDI in Taiwan is Japan. The last fifty year colonial rule of Japan over Taiwan has established a very close economic and trade relationship between Japan and Taiwan. During the Japanese colonization period, Japanese Empire invested heavily in Taiwan. Japanese Empire also brought in many technologies to Taiwan. This trend has not died down, in fact, till today Taiwan has shown support for Japanese firms to invest and become partners of their new business ventures in order to access the needed technologies to Taiwan. In addition, Japan has a very close geographical location with Taiwan, which has aided in the reduction of 
transportation cost and provides a convenient mean of transferring technologies to Taiwan. Japanese firms have often placed Taiwan top on the list when it come to relocating their firms. The key being the advantage Taiwan offers in terms of the island's competitive labor cost when compared to the excessively high labor cost of the Japanese firms (Hwang, 1991). Taiwan's labor cost will be one of the explanatory variables to be considered in my empirical analysis.

Figure 2.2 The Average Five Major FDI Contributors To Taiwan

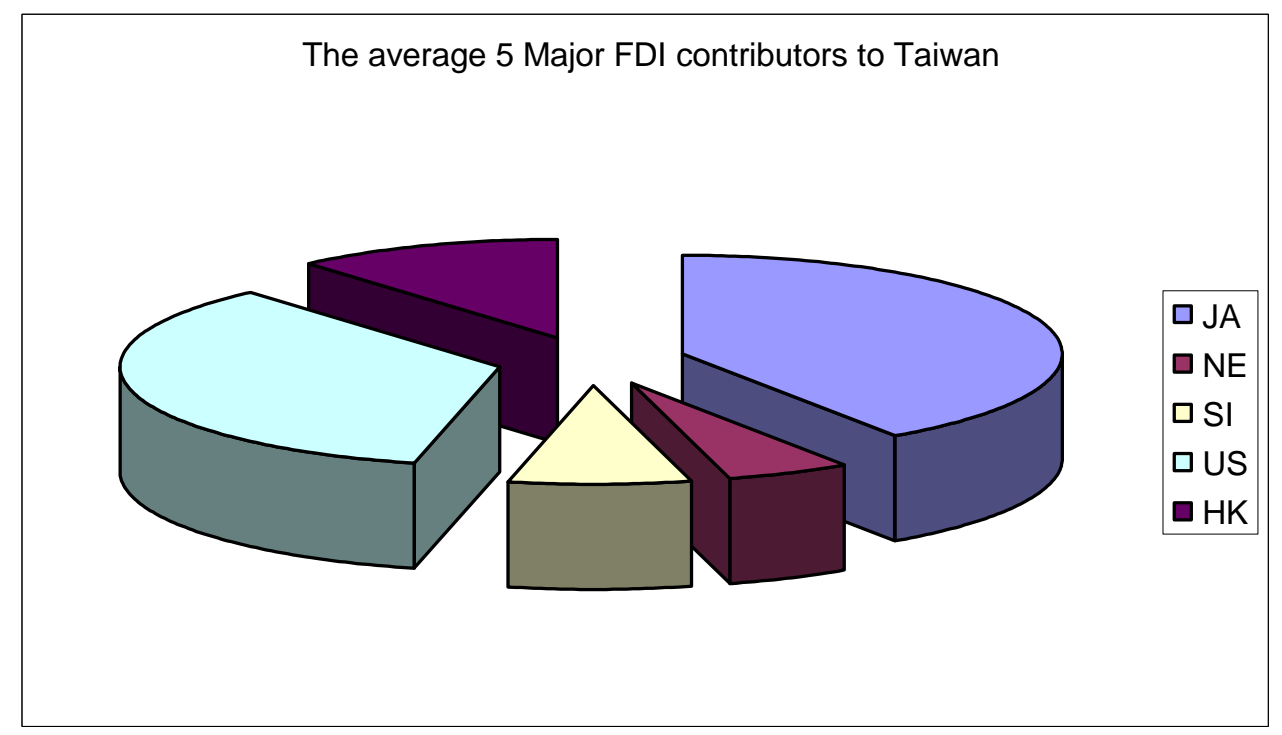

Sources: Investment Commission M.O.E.A. (1992)

United States is the second largest source FDI contributing country to Taiwan. The American investment is welcomed because of the close political and economic relationship between Taiwan and the United States in view of the Taiwan Relations Act (TRA) that was passed in 1979. TRA is the first legislation in American history whose purpose was to define, govern, and oversee U.S. relations with a specific foreign country (in this case, that is Taiwan) (Chang, 1988). "In the nine years preceding 1979, total US private investment in Taiwan was only US\$ 12 million. In 1979, the year just passed the (TRA), the US private investment had been US\$80million. During the nine years (1969-1978), US private investment in Taiwan economy amounted to US\$1.6million" (Chang, 1988). In addition, Hong Kong is the third largest source country. With an annual flow of investment of US\$120 millions dollars. One of the reasons why Hong Kong is one of the greatest sources of FDI in Taiwan is because they may have similar characteristics in cultural and linguistic which can reduce some of the informational and contractual costs.

\section{The Major Determinants Of Taiwan's FDI}

What factors draw foreign investment into Taiwan? As Tsai (1991) mentioned in his paper, the determinants of foreign direct investment are grouped into demand-side and supply side factors. The demand-side determinants include political stability, labor cost, market size, regional economic integration, and investment incentives offered by the host country. The supply side determinants consist of economies of scale, oligopoly reaction, product life cycle and internalization. The factors are also in line with other research works and empirical papers that have been written about FDI in Taiwan. Riedel (1975) talked about four factors that have been identified as the major determinant of the growth of FDI in Taiwan. Those are labor costs, distance costs, governmental influences and political stability and security. Tsai (1991) shows that only labor cost, market size and government incentive policies are considered to be important as determinants of FDI in Taiwan. 
In this paper, only the demand side determinants of FDI are considered; as studies on the supply side factors are constrained by the lack of availability of data. The demand side determinants namely are market size, labor cost, distance cost and some incentive policies. Riedel (1975), Lim (1983) and Torrisi (1985) have shown that several demand-side determinants are crucial in attracting FDI.

\section{Market Size}

There are two general hypotheses concerning the domestic market, namely, the market size hypothesis and the growth hypothesis (Tsai, 1991). The market size hypothesis states that when the size of the market of a particular host country has grown large enough to a certain level, the host country can become the target for the inflow of FDI. On the other hand, the growth hypothesis states that as GDP grows, the market size will inevitably grow, and foreign firms will start investing and increasing their investment with the expansion of the market (Torrisi, 1985). However, in this paper, we will test for a similar version of the market size hypothesis although it is interpreted quite differently. In the same spirit of the market size hypothesis, the relative market size of the two countries is considered. The ratio of the real GDP of the country contributing FDI in Taiwan to the real GDP of Taiwan is used as a proxy for the relative market size of the FDI contributing country versus that of the host country. As the market size of Taiwan increases over time relative to that of the FDI contributing country across time (i.e. we expect the value of this proxy to be decreasing), the higher is FDI into Taiwan; hence the variable FDI is expected to be negatively correlated to the proxy.

\section{Labor Cost}

One would expect that if the host country has a competitive labor cost relative to the FDI contributing country, there would be a higher inflow of FDI into the host country. Therefore, it is normal to predict that the FDI of Taiwan and the relative real wage between FDI contributing country and the host country will have a positive relationship. Several other studies have taken issue on labor cost as the determinant of FDI into Taiwan. Riedel (1975) found that low labor costs to be important in attracting FDI. However, in Wu (1985) recent study, the continual growth of FDI in Taiwan in the face of rising labor costs indicates that cheap labor may not be as important as expected.

\section{Distance Cost}

Does distance cost have an impact on FDI? Benito and Gripsrud (1995) enumerated three different dimensions of the concept of distance. First, distance can be understood in a physical sense, usually termed as geographical distance. Second, distance can refer to differences, or the degree of difference, between entities along some chosen characteristic, such as differences in culture between countries (cultural distance) and in the level of economic development (Benito and Gripsrud called this as economic distance). Alongside the definitions offered by Benito and Gripsrud, one would expect that FDI of one country would gradually take place in another less distant country. One of the reasons is that it may reduce some of the transportation costs. One country will also take cultural distance as an important factor of FDI. The foreign investors may be more likely to invest in a country where it has similarity in cultural distance. It may reduce the informational costs for business transactions taking place between two countries. In addition, it is easier for the foreign firms to monitor and communicate with the employees in a country where there is common language and similar culture. Therefore, it is expected that there will be an inverse relationship between the relative distance cost and FDI and this has been tested to be true in several studies.

Kulchycky (1990) found that distance cost has a significantly negative impact on the internalization of U.S. multinational firms. Similar pattern was found by Davidson (1980), Luostarinen (1979), Joanson (1975) and Wiedersheim-Paul (1975). Davidson (1980) and Luostarinen (1979) found that "US firms have usually made their first foreign investments in countries like Canada and the UK and Finnish firms have tended to go to Sweden when undertaking their first establishment abroad." In this paper, only the geographical distance is considered to test if it is a significant variable in determining FDI. However, whether the first FDI are made in countries that are geographically closer to home country than later FDI is not considered in this paper, unlike other researcher papers. 


\section{Incentive Policies}

Before investing in a country, foreign investors may ask questions like: does the host country provide any support or benefits to business people? Also, since tax directly affects firm's profits, investors' prime consideration may include: does the host country have a double-taxation treaty or any investment treaty with my home country? Yannopoulos (1987) conducted a study on tariff preferences and FDI. Yannopoulos (1987) found that the size and direction of FDI when generated by the establishment of a preferential trade arrangement are determined by the effects on trade due to the changes in the structure of tariffs. Therefore, in this competitive world, governments in many countries should offer the right set up of investment incentives like tax holidays or tax concessions to attract more FDI from other countries. Stable macroeconomic policies such as low inflation rate, reasonable exchange and interest rates and a well-managed economy are also important for attracting the FDI. Taiwan has offered several incentives for FDI provided by the 1960 "Statute for the Encouragement of Investment" which can be briefly summarized as follows.

There is 1) a five year business income tax holiday on new investments and expanding investments which increase productive capacity by $30 \% ; 2$ ) a reduction of business income tax from a maximum of $32 \%$ previously to a maximum of $18 \%$ and 3) an income tax exemption on reinvested profits. Through the 1970s, the Statute for the Encouragement of Investment was revised nine times to promote Taiwan as a destination for FDI (Investment Law of the Republic of China, 1988). Through the 1980s, it was amended again twice. The government began a series of changes in policy to liberalize its goods and financial markets with explicit goal of making Taiwan an even more attractive destination for FDI. These moves included significant tariff reductions and relaxation and abolition of nontariff barriers so that by the end of the decade of the 1980s, these import restrictions were practically negligible in magnitude (Ho Ming-Yu, 2002).

Besides the Statute for the Encouragement of Investment, in 1965 the government of Taiwan also enacted the Statute for the Establishment and Management of Export-Processing Zone (EPZs) (Ho Ming-Yu, 2002). EPZs offered complete exemption from custom duties, commodity and sales taxes, provided other incentives for export-oriented firms to set up in zones. These EPZs had the effect of multiplying Taiwan's links with foreign firms through FDI. Typically, a multination corporation would invest in Taiwan, set up a large manufacturing plant and generate a market for a host of small local suppliers and assembly operations.

Taiwan's current policy toward FDI is to emphasize the growth of high-technology industries. Preferential tax measure that includes credits for R \&D investments and five- year exemptions or shareholder investment credits for companies in high-technology industries are implemented.

From the above policies, it is clear that Taiwan has always taken the stance of attracting foreign investors. To capture this policy incentives effect is not an easy task. If our framework of analysis is based on a time series regression, this will be easily captured by a time dummy. In our framework of analysis of a panel data regression, we may not be able to take into account of the structural break meaningfully by including a time dummy in our regression. Although, it would be enlightening to have data set on various governmental policy, such as tax incentives, that could potentially be used to explain the effect of government policy on FDI in Taiwan. Unfortunately, due to data constraint, it is decided not to pursue this matter. This issue, however, is an interesting one and can be pursued as a research topic in the future.

\section{Literacy Rate}

The current literature on human capital often uses literacy rate as a proxy for an educated labor force. It is envisaged that the higher the literacy rate, the cost of employing laborer will also rise. Hence, this variable, which is positively correlated with the real wage, indirectly captures information on the cost of employing human capital in the FDI contributing country. Hence if there is a rising literacy rate, the motivation to invest overseas is higher given that the cost incurred may be lower in another country. 


\section{Other Factors}

Investors are also concerned about the political stability of the host country. One may not want to invest in a country where has internal political, economic, and social instability. Also, the unfriendly attitude of the host country's government may create a negative image to the investors. As a result, investors may tend to invest in a country with similar ethnic and culture but avoid investing in any risky countries.

\section{METHODOLOGY}

The data set of this paper comprises various macroeconomic variables from the following nine countries: Hong Kong, Australia, United States, Japan, Netherland, United Kingdom, Singapore, Panama and Canada. These nine countries are the largest source of FDI contributing countries in Taiwan. The macroeconomic variables are FDI, GDP, GDP per capita, literacy rate, distance, and average wage. The sample period is from 1983 to 1997 . This sample period is chosen since before 1983, FDI in Taiwan was not significant and global foreign direct invest did not grow until 1980s. The sample ends in 1997 because of the Asian Financial Crisis that occurs in that year. The crisis will have significant impact on the FDI in Taiwan that may distort the analysis.

\section{Sources Of The Data}

Secondary Data were used from various Statistical Yearbooks and data banks. The FDI figures are taken from the Investment Commission M.O.E.A. (1992). The FDI is the annual inflow of real contracted FDI in Taiwan and is measured in US \$1000. GDP and per capita GDP are taken from the World Development Distributor (1999 \& 2000). They are measured at constant market price of 1995 and are measured in millions of US dollars. The literacy variable is measured in terms of secondary school enrollment and it is expressed in percentage of the labor force. This data is taken from the Economic Indicator (2000). The distance data between Taiwan and the nine largest source countries are taken from the Direct-Line Distance (1999) and they are measured in kilometers.

The first attempt to use the unit labor cost did not work out for reasons that many of the sample countries do not publish such data. The annual wage rate from the manufacturing sector is used as a proxy for unit labor cost. The annual wage rate data are taken from various issues of Labor Statistical Yearbook (International Labor Office Geneva). The manufacturing wages are express in US\$ per annual.

\section{DATA ANALYSIS}

\section{Empirical Framework}

The demand side determinants will be tested using aggregate variables as discussed earlier. These variables are GDP per capita ratio of FDI contributing country to Taiwan, distance, literacy rate and the relative labor cost. The panel data regression model is as follows:

$\log \left(\mathrm{FDI}_{\mathrm{ij}}\right)=\alpha_{\mathrm{j}}+\beta_{1} \log \mathrm{GDP}_{\mathrm{j}} / \log \mathrm{GDP}_{\mathrm{i}}+\beta_{2} \log \left(\right.$ Distance $\left._{\mathrm{ij}}\right)+\beta_{3}\left(\right.$ literacy $\left._{\mathrm{j}}\right)+\beta_{4}\left(\right.$ labor cost $_{\mathrm{j}} /$ labor $\left.\cos _{\mathrm{i}}\right)+\mu_{\mathrm{ji}}$

where $\quad \mathrm{i}=$ Taiwan and $\mathrm{j}=$ other countries (USA, Japan, China, Singapore, etc.)

As discussed earlier, the sign of $\beta_{1}$ is expected to be negative. If the market size of Taiwan increases over time relative to that of the FDI contributing country (i.e. the value of $\log \mathrm{GDP}_{\mathrm{j}} / \log \mathrm{GDP}_{\mathrm{i}}$ is expected to be decreasing), the higher is FDI into Taiwan. The coefficient $\beta_{2}$ is expected to be negative since longer distance would translate into higher transportation cost so that the level of FDI would be lower. A high relative labor cost would suggest that there is greater incentive to invest in Taiwan; hence the level of FDI is positively correlated with the relative labor cost variable. Finally, a higher literacy rate would suggest a more educated workforce, which has to be compensated with higher wages for return to schooling. Hence, this is a push factor for foreigners to invest in Taiwan. Hence the expected sign of $\beta_{3}$ is positive. 
Why Panel Data is being used in this study? The advantages of using panel data are many. Hsiao (1985), Klevmarken (1989) and Solon (1989) listed several benefits from using panel data. Moreover, panel data also gives more informative data, more variability, less collinearity among the variables, and more degrees of freedom hence more efficiency.

The following are the three types of panel analytic models used: (1) Pooled regression model (2) Fixed effect model and (3) Random effect model. Pooled regression model is one type of model that has constant coefficients, referring to both intercepts and slopes. For this model researchers can pool all of the data and run an ordinary least squares regression model. The fixed effect model is the differences across cross-sectional units that can be captured in differences in the constant term and the intercept term of the regression model varies across the cross sectional units. In this model, $\alpha_{j}$ is the intercept term that represents the fixed country effect. On the other hand, in the random effect model, the individual effects are randomly distributed across the cross-sectional units and in order to capture the individual effects, the regression model is specified with an intercept term representing an overall constant term (Seddighi, 2000).

Which is the best among the three panel analytic models to fit the data? In this panel data study, only the cross sectional data on nine countries over a fifteen year period is collected. The cross sectional sample are relatively small and the sample exhausts all cross-sectional units. Therefore, it is appropriate to use the fixed effect model. However, the pooled regression model and the random effect model will also be considered for the purpose of comparison. It is also the convention to model the pooled regression model, the fixed effect and random effect models and use R-squared, adjusted R-squared and the $\mathrm{Wu}$ and Hausman test to decide statistically on the appropriate model to be used.

\section{Descriptive Statistics}

The result of FDI from nine largest sources countries from 1983 to 1997 is shown in Table 4.2. From these nine countries, Japan, United States, Hong Kong, Singapore and Netherlands have the largest outflow of FDI to Taiwan. Their annual outflows going into Taiwan are US $\$ 461$, US $\$ 390$, US $\$ 127$, US $\$ 88$, and US $\$ 120$ millions dollars, respectively (Investment Commission M.O.E.A., 1992). The FDI graphs (see Graph 4.1 in Appendix) show that these largest five source countries mostly have upward trend especially for Singapore.

For Japan, the FDI to Taiwan starts to grow in 1984 and grows rapidly in the period of 1985 and 1989. This may be due to an appreciating yen that strengthened the purchasing power of the Japanese. However, Japanese FDI to Taiwan suddenly declined in 1990 and continued to decrease in 1991 and 1992. In 1990, Japan's financial bubble burst and "the Japanese economy went through a depression and most companies were losing interest in FDI, because the profit rate declined significantly." (Matsugi, Oberhauser \& Schober, 1996, pp. 29). The FDI has not started to recover until 1993 and the FDI starts to increase sharply again in 1996.

For U.S., it has a downward spike during 1994 to 1996. GDP of the U.S. is checked to see if the country had contraction during that time frame. However, it turned out that there was not. Hence, the reason for the sudden decline in 1995 is inexplicable.

Table 4.2 Statistics Of FDI From The Nine Largest Source Countries

\begin{tabular}{lccccccccc}
\hline \multicolumn{10}{c}{ Sample: 1983- 1997 In US \$1000 } \\
\hline & AU & CA & HK & JA & NE & PA & SI & UK & US \\
Mean & 55310.93 & 12799.93 & 127257.1 & 461959.4 & 60117.50 & 32440.14 & 88409.14 & 58605.50 & 390982.7 \\
Max. & 596197.0 & 74332.00 & 232099.0 & 851139.0 & 159253.0 & 60468.00 & 449976.0 & 193516.0 & 1275623. \\
Min. & 310.0000 & 63.00000 & 13980.00 & 145236.0 & 3091.000 & 261.0000 & 206.0000 & 983.0000 & 93294.00 \\
S.D. & 156590.6 & 19586.03 & 68982.09 & 214988.5 & 41022.33 & 21691.13 & 117187.8 & 48177.00 & 299314.5 \\
\hline
\end{tabular}


Table 4.3 in Appendix shows that the results of the GDP at levels for nine major FDI contributing countries to Taiwan. Japan and U.S. have the largest market size among these countries. Their annual GDP level are \$US 458 and \$US 645 billions, respectively (World development distributor, $1999 \& 2000$ ). This is in line with the literature on the determinants of FDI in the host country. A large GDP level indicates a large market size. Foreign firms increase their investment with the expansion of the market. This has often been cited as the market size effect (Scaperlanda \& Mauer, 1969; Torrisi, 1985). The GDP graphs in Table 4.3 suggest that GDP of all the countries have an upward trend. Canada is the only exception with its GDP level picks up rather sharply between the period of 1984 and 1986. The sudden increase in GDP could possibly due to the migration boom during that period of time. As for Panama, GDP contracts between the period of 1987 and 1989. During 1987, there was a national civil crusade in Panama. "During the June 1987 crisis, business groups played a key role in the organization. A total of more than 130 business, professional, civic, and labor groups joined the crusade, which undertook the task of organizing, directing, and coordinating the campaign to force Noriega out of power and to reduce the role of the military in government" (Zuljan, 2000). The continued civil strife badly damaged panama's economy.

\section{EMPIRICAL RESULTS}

As earlier described, the panel data regression model is as follows:

$\log \left(\mathrm{FDI}_{\mathrm{ij}}\right)=\alpha_{\mathrm{j}}+\beta_{1} \log \mathrm{GDP}_{\mathrm{j}} / \log \mathrm{GDP}_{\mathrm{i}}+\beta_{2} \log \left(\right.$ Distance $\left._{\mathrm{ij}}\right)+\beta_{3}\left(\right.$ literacy $\left._{\mathrm{j}}\right)+\beta_{4}\left(\right.$ labor cost $\left._{\mathrm{j}} / \operatorname{labor}_{\text {cost }}\right)+\mu_{\mathrm{ji}}$

where $\mathrm{i}=$ Taiwan and $\mathrm{j}=$ other countries (USA, Japan, China, Singapore, Hong Kong, Australia, Netherland, Panama, and Canada.)

The following empirical models were estimated: Pooled regression model; Fixed Effect model and Random Effect model.

The first model that is estimated is the Pooled regression model.

\section{(1) Pooled Regression Model}

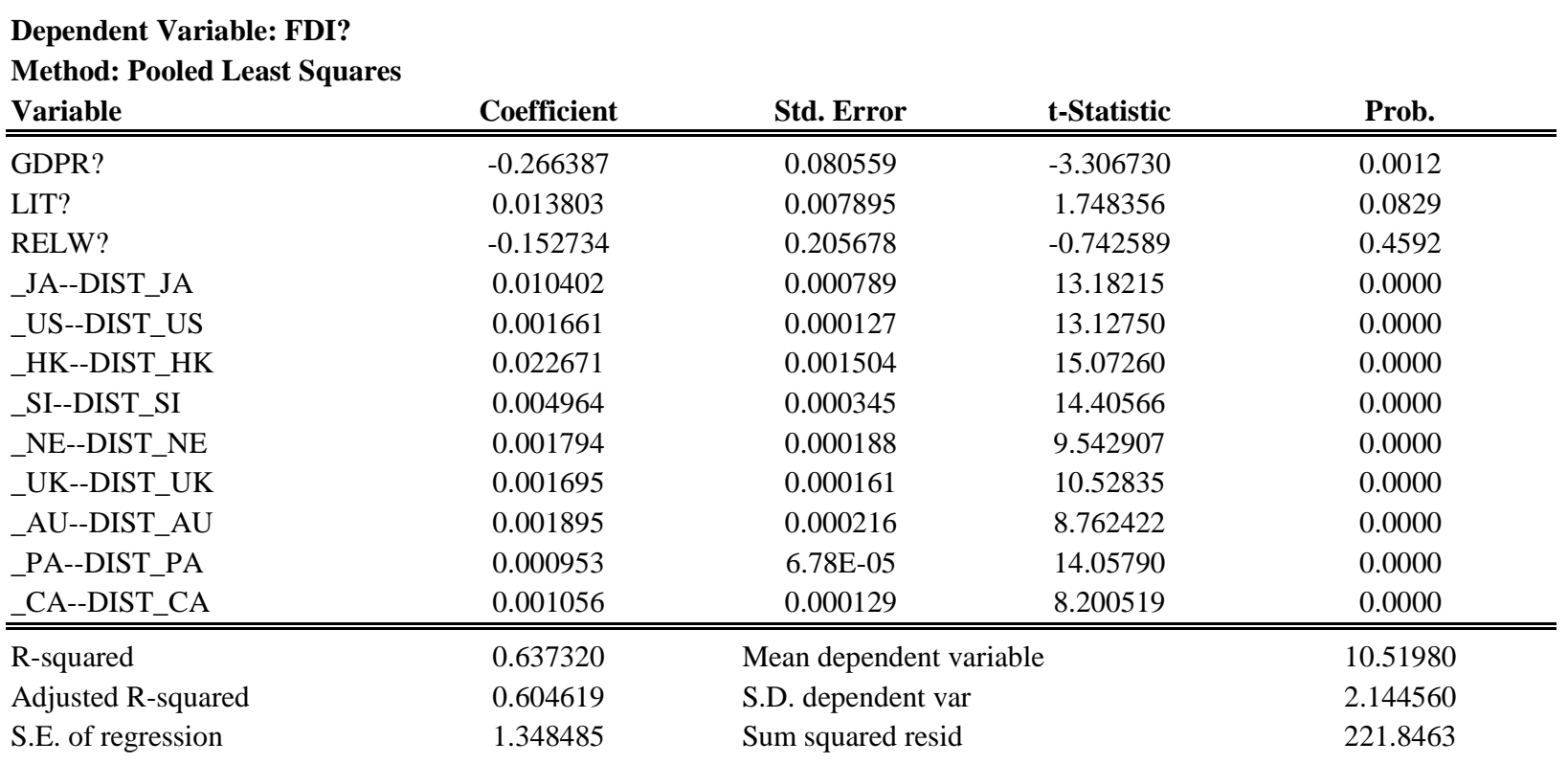


From the p-values of the explanatory variables, it is clear that only the variables, relative market size and distance for the nine countries, are significant at $5 \%$ level. Literacy rate is not significant at the $5 \%$ level although it is significant at the $10 \%$ level.

All variables appear to have the correct signs except for the relative labor costs. The sign of the relative labor costs is reversed from the postulated one. It appears at the first sight to be counterintuitive since the higher labor cost in the FDI contributing country should enhance FDI in Taiwan. However, the negative sign could be due to the crude proxy that is adopted. In many of the literatures, the efficiency real wage is used instead of wage income. Failure of taking into account of the efficiency measurement may have contributed to the wrong negative sign.

There is also no reason for a country say, US FDI in Taiwan to expand with the increase in the real wage difference between the two counties. As long as the real wage difference between the United States and any other potential host country is wider than that between the United States and Taiwan, US firms should not invest in Taiwan according to the labor cost hypothesis.

This model appears to support the market size hypothesis, given that the coefficient of the market size proxy variable is significantly large in comparison to the other variables.

(2) Fixed Effect Model

Dependent Variable: FDI?

Method: GLS (Cross Section Weights)

\begin{tabular}{|c|c|c|c|c|}
\hline Variable & Coefficient & Std. Error & t-Statistic & Prob. \\
\hline GDPR? & -0.208745 & 0.048736 & -4.283135 & 0.0000 \\
\hline LIT? & 0.012805 & 0.007345 & 1.743454 & 0.0838 \\
\hline RELW? & -0.107562 & 0.147062 & -0.731409 & 0.4659 \\
\hline \multicolumn{5}{|l|}{ Fixed Effects } \\
\hline JA-C & 13.22021 & 0.512615 & 25.78974 & \\
\hline _US-C & 12.75937 & 0.731854 & 17.43431 & \\
\hline _HK-C & 11.26747 & 0.609179 & 18.49616 & \\
\hline _SI-C & 9.857890 & 1.900126 & 5.188019 & \\
\hline _NE-C & 10.31921 & 0.903022 & 11.42742 & \\
\hline _UK-C & 10.13396 & 1.065018 & 9.515295 & \\
\hline _AU-C & 8.301838 & 1.660462 & 4.999716 & \\
\hline - PA-C & 9.248093 & 1.493478 & 6.19232 & \\
\hline$-\mathrm{CA}-\mathrm{C}$ & 7.686479 & 1.820015 & 4.223305 & \\
\hline \multicolumn{5}{|l|}{ Weighted Statistics } \\
\hline R-squared & 0.971441 & Mean dependent var & & 13.93788 \\
\hline Adjusted R-squared & 0.968866 & S.D. dependent var & & 7.527410 \\
\hline S.E. of regression & 1.328196 & Sum squared resid & & 215.2209 \\
\hline
\end{tabular}

The result of the fixed effect model resembles that of the Pooled regression model. In particular, only the variable market size remains to be significantly different from zero at the $5 \%$ level. The relative market size hypothesis continues to hold in this model. The relative labor costs continue to be signed wrongly. However, the Rsquared and the adjusted R-squared of this model represents a better fit of the model.

It is clear from the t-statistics that the intercepts are all significantly different from zero at the 5\% level of significance for a t-critical value of 1.645 . This may not be at all surprising since the intercept terms may subsume the distance variable, which were proven to be significant in the Pooled regression models. 
(3) Random Effect Model

\begin{tabular}{|c|c|c|c|c|}
\hline \multicolumn{5}{|c|}{$\begin{array}{l}\text { Dependent Variable: FDI? } \\
\text { Method: GLS (Variance Components) }\end{array}$} \\
\hline Variable & Coefficient & Std. Error & t-Statistic & Prob. \\
\hline $\mathrm{C}$ & 10.26649 & 0.932678 & 11.00754 & 0.0000 \\
\hline GDPR? & -0.240783 & 0.081606 & -2.950544 & 0.0038 \\
\hline LIT? & 0.015241 & 0.007791 & 1.956322 & 0.0526 \\
\hline RELW? & -0.150569 & 0.204299 & -0.737003 & 0.4624 \\
\hline \multicolumn{5}{|l|}{ Random Effects } \\
\hline$-\mathrm{JA}-\mathrm{C}$ & 2.877638 & 0.639268 & 4.501461 & \\
\hline _US-C & 2.391001 & 0.830833 & 2.877837 & \\
\hline _HK-C & 0.892273 & 0.570884 & 1.562966 & \\
\hline _SI-C & -0.411003 & 1.873173 & -0.21942 & \\
\hline -NE$-\mathrm{C}$ & 0.005879 & 0.899751 & 0.006534 & \\
\hline _UK-C & -0.166245 & 1.088902 & -0.15267 & \\
\hline _AU-C & -1.873682 & 1.6854 & -1.11171 & \\
\hline - PA-C & -1.067772 & 1.465201 & -0.72875 & \\
\hline$-\mathrm{CA}-\mathrm{C}$ & -2.456246 & 1.740336 & -1.41136 & \\
\hline \multicolumn{5}{|c|}{ GLS Transformed Regression } \\
\hline R-squared & 0.594973 & Mean dependent var & & 10.51980 \\
\hline Adjusted R-squared & 0.585626 & S.D. dependent var & & 2.144560 \\
\hline S.E. of regression & 1.380494 & Sum squared resid & & 247.7494 \\
\hline
\end{tabular}

The random effect model results differ quite significantly from that of the fixed effect model. Although the relative market size variable remain to be significantly different from zero at the $5 \%$ level together with the intercept, in this model not all the country intercept terms are significant. In fact, only the intercept terms of US and Japan are significantly different from zero at the $5 \%$ level of significance for a t-critical value of 1.645 .

What is of interest is that throughout the three models, the magnitude of the coefficient of the relative market size variable averages at -0.22 and it is bigger than the other two variables. Hence, this study can conclude that the relative market size hypothesis is a key determinant of FDI in Taiwan.

In the above two models of fixed effect and random effect models, the study has developed two estimators that have different properties depending on the correlation between $\alpha_{i}$ and the regressors. Specifically, if the effects are uncorrelated with the explanatory variables, the random effects (RE) estimator is consistent and efficient. The fixed effects (FE) estimator is consistent but not efficient. However, if the effects are correlated with the explanatory variables, the FE estimator is consistent and efficient but the RE estimator is now inconsistent. Hence, it is natural to proceed by computing the $\mathrm{Wu}$-Hausman test to identify which estimator is correct.

The test is set up as follows as illustrated in Johnston and Dinardo (1997):

$H=\left(\hat{\beta}_{R E}-\hat{\beta}_{F E}\right)^{\prime}\left(\Sigma_{F E}-\Sigma_{R E}\right)^{-1}\left(\hat{\beta}_{R E}-\hat{\beta}_{F E}\right)$

where: $\mathrm{RE}=$ random effect and $\mathrm{FE}=$ fixed effect

The $\mathrm{H}$ statistic is distributed asymptotically as chi-square with k-degrees of freedom under the null hypothesis that the random effects estimator is correct. Our computation of the Wu-Hausman test gives a statistic 
value of 3.532, which is greater than the critical value of .352 with three degrees of freedom. This suggests that the null hypothesis is rejected, and conclude that there is insufficient statistical evidence to reject fixed effect estimator.

\section{SUMMARY, CONCLUSIONS, AND RECOMMEDATIONS}

\section{Summary}

The objective of this paper is to test the determinants of FDI in Taiwan. Based on the current literature on FDI in other countries, the determinants of FDI are relative market size, relative labor cost, distance and literacy rate. Data of these variables were collected from various published statistical yearbooks and online data banks. The study then proceeds to estimate the panel data regression model using these explanatory variables.

\section{Conclusions}

Empirical Analysis of this study finds that relative market size consistently proves to be a key explanatory variable in Taiwan's FDI inflow. The distance variable also partly explains the level of FDI in Taiwan, but to a lesser extent. However, the much often cited cause of FDI, relative labor cost, is not significant in explaining the level of FDI in Taiwan. Literacy rate, on the other hand, which proxies labor costs indirectly appear to be weakly significant in explaining FDI inflow into Taiwan.

This study is not without limitation. In particular, due to data constraint, a better proxy for the real wage efficiency unit have not been employed to better represent the relative labor costs between the FDI contributing country and Taiwan. In addition, the study does not take into account of other less-quantifiable factors such as the ROC's government policy as well as cultural affinity.

\section{Recommendations}

Clearly, this is a purely empirical piece of work that does not provide any theoretical underpinnings. A better way of approaching this whole issue of determining FDI in Taiwan may be to model the Taiwanese economy as a small open economy and build some tractable model where the dynamic of FDI from other FDI contributing countries could be traced under some macroeconomic environment.

\section{REFERENCES}

1. Arellano, M. (2003). Panel data econometrics. Oxford; New York: Oxford University Press.

2. Baltagi, B.H. (1995). Econometric Analysis of Panel Data. New York: Wiley.

3. Bende-Nabende, A. \& Ford, J.L. (1998). FDI, Policy Adjustment and Endogenous Growth: Multiplier Effects from a Small Dynamic Model for Taiwan, 1959-1995. World Development, 26, 1315-1330.

4. Benito R.G. \& Gripsrud G. (1995). The internationalization process approach to the location of foreign direct investments: An empirical analysis. World Development, 26(7), 1315-1330.

5. Central Bank of China (1981). Balance of payments, Taiwan District. Taipei: Author.

6. Chang, K.Y. (1988). ROC-US Relations Under The Taiwan Relations Act: Practice and Prospects. Taipei, Taiwan, Republic of China: Institute of International relations, National Chengchi University.

7. Chen, T.J. (1992). Determinants of Taiwan's direct foreign investment: The case of a newly industrializing country. Journal of Development Economics, 39, 397-407.

8. Davidson, W.H. (1980). The allocations of foreign direct investment activity, country characteristics and experience effects. Journal of International business Studies, 11, 9-22

9. Department of Statistics of ROC (1987, 1996 \& 1998). Statistical Yearbook of Taiwan Province. Nantou: Author.

10. Development Data Group and Development Economics of the World Bank (1999 \& 2000). World Development Indicators [CD-Rom]

11. Fei, J.C.H., Ranis, G., \& Kuo, S.W.Y. (1979). Growth with equity: the Taiwan case. New York: Oxford University Press. 
12. Fitzpatrick, G.L. (1986). Direct-lines distances. Metuchen, N.J.: Scarecrow Press.

13. Gereffi, G. \& Wyman, D.L. (Ed.). (1990). Manufacturing miracles: paths of industrialization in Latin America and East Asia. Princeton, N.J.: Princeton University Press.

14. Hill, R.G., Griffiths, W.E. \& Judge, G.G. (2001). Undergraduate econometrics. New York: Wiley.

15. Ho, M.Y. (2002). In Service of Growth: Legal Regimes, FDI and Taiwan's Economic Development. Retrieved Feb $22^{\text {nd }}, 2005$, from http://www.iias.nl/iiasn/32/RR_in_service_of_growth.pdf

16. Hollerman, L. \& Myers, R.H. (Ed.). (1996). The effect of Japanese investment on the world economy: a sixcountry study. Stanford, Calif.: Hoover Institution Press.

17. Hsiao, C. (1985). Benefits AND Limitations of Panel Data. Econometric Reviews, 4, 121-174.

18. Hwang, Y.D. (1991). The Rise Of a New World Economic Power: Postwar Taiwan. New York: Greenwood.

19. International Labor Office Geneva. (1984-1998). Labor Statistical Yearbook. Geneva: Author.

20. International Monetary Fund (2003). International financial statistics. Washington, D.C.: Author

21. Investment Commission Ministry of Economic Affairs. (1992). Statistics on overseas Chinese \& foreign investment technical cooperation, outward, investment, outward technical cooperation, indirect mainland investment. Taipei City: author.

22. Investment law of the Republic of China. (1988). Statue for the Encouragement of investment. Taipei, Taiwan, Republic of China: Industrial development and investment center: Author.

23. Klevmarket, N.A. (1989). Fiscal incentives and direct foreign investment in less developed countries. The Journal of Development Studies, 19, 207-212

24. Lee, T.H. (1979). International Capital Flows in Economic Development of Taiwan. Ithaca: Cornell University Press.

25. Lim, D. (1983). Fiscal incentives and direct foreign investment in less developed countries. The Journal of Development Studies, 19, 207-212.

26. Matsugi, T., Oberhauser, A., \& Schober, F. (1996). The integration and adjustment of global economies: direct investment, financial institutions, and international business policies. Berlin: Duncker \& Humblot.

27. Poniachek, H.A. (1986). Direct Foreign Investment in the United States. Lexington, Mass: Lexington Books.

28. Ranis, G. \& Schive, C. (1985). Foreign Trade and Investment: Economic Development in Newly Industrializing Asian Countries. Madison: University of Wisconsin Press.

29. Reuber, G.L. \& Crookell, M.E. (1990). Private Foreign Investment. Oxford: Clarendon Press.

30. Riedel, J. (1975). The nature and determinants of export-oriented direct foreign investment in developing countries: A case study of Taiwan. Weltwirischaftliches Archiv, 111, 505-528.

31. Schive, C. \& Majumdar, B.A. (1990). Direct Foreign Investment and Linkage Effects: The Experience of Taiwan. Canadian Journal of Development Studies, 6(2), 326-360.

32. Seddigi, H. \& Lawler, K.A. (2000). Econometrics: a practical approach. New York: Routledge.

33. Solon, G.S. (1989). The value of Panel Data in Economic Research. New York: Wiley.

34. Torrisi, C.R. (1985). The determinants of direct investment in a small LDC. Journal of Economic Development, 10, 29-45.

35. Tsai, P.L. (1991). Determinants of Foreign Direct Investment in Taiwan: An Alternative Approach with Time-Series Data. World Development, 19, 275-285.

36. Wei, S.J. (1995). Attracting Foreign Direct investment: Has China Reached Its Potential? The China Economic Review, 6 (2), 187-199.

37. Wu, H.L. (1985). The Comparisons of Wages and Productivity Between Taiwan and Her Competing Countries. Taipei: Chung Hua Institution for Economic Research.

38. Wu, R.I. (Ed.). (1995). The influences of US. Firms on the Economy of Taiwan. Taipei: Institute of American Culture.

39. Yannopoulos, P.A. \& Jeffrey B. N. (1987). A balanced growth version of the linkage hypothesis: A test. Quarterly Journal of Economics, 8, 157-171.

40. Zikmund, W.G. (2000). Business research methods ( $6^{\text {th }}$ ed.). Ohio: South-Western.

41. Zuljan, R. (2000). National Civic Crusade in Panama 1987. Retrieved Feb 25 $5^{\text {th }}$, 2005, from http://www.onwar.com/aced/chrono/c1900s/yr85/fpanama1987.htm/ 


\section{APPENDIX}

\section{Graph 4.1}

The FDI s from the five largest source countries (1983-1997)

Y-axis: in \$US 1000

X-axis: years
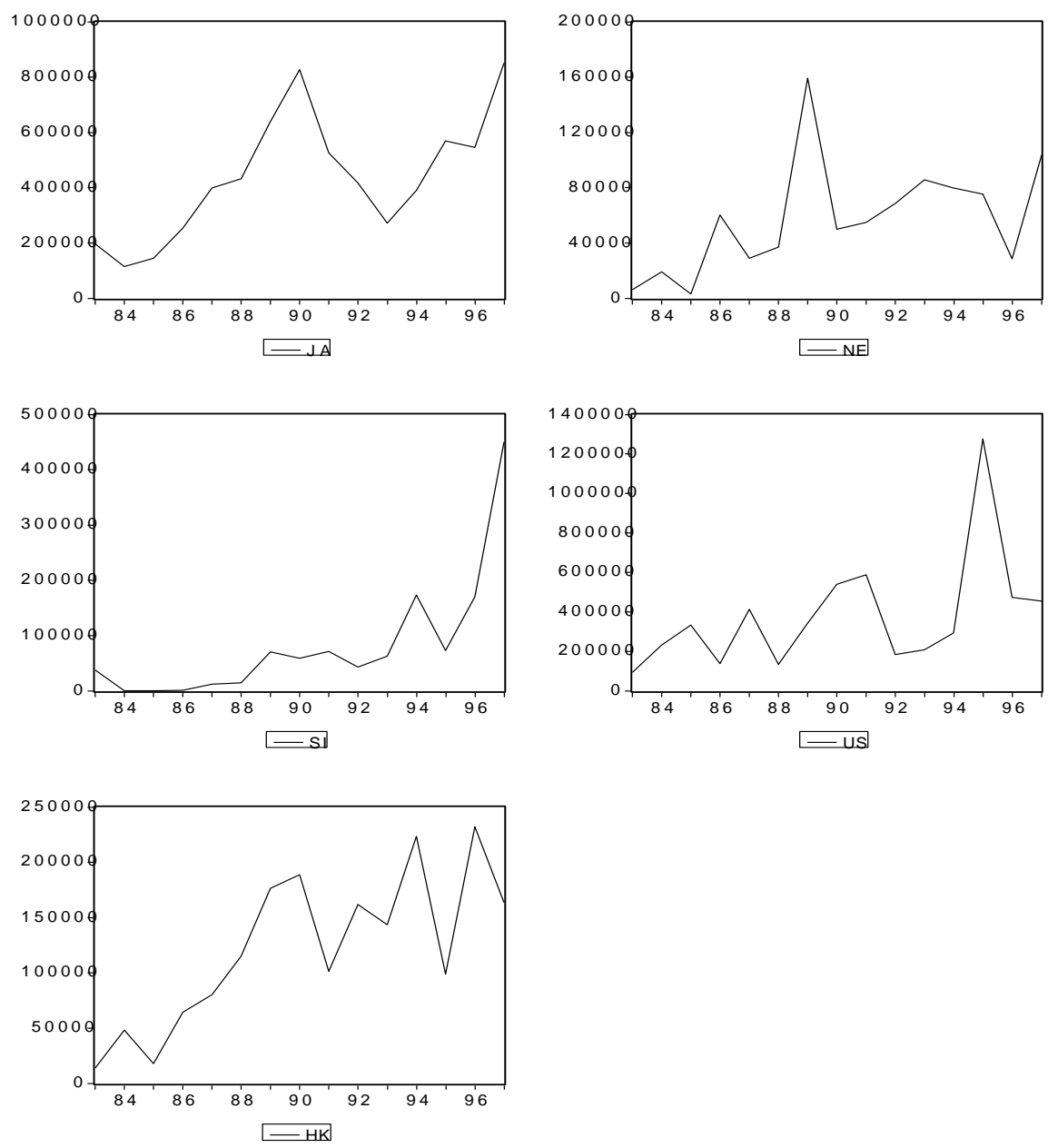

Sources: Investment Commission M.O.E.A. (1992) 
Graph 4.3 GDP at levels for nine major FDI contributing countries to Taiwan

Y-axis: in million US dollars $\mathrm{X}$-axis: years
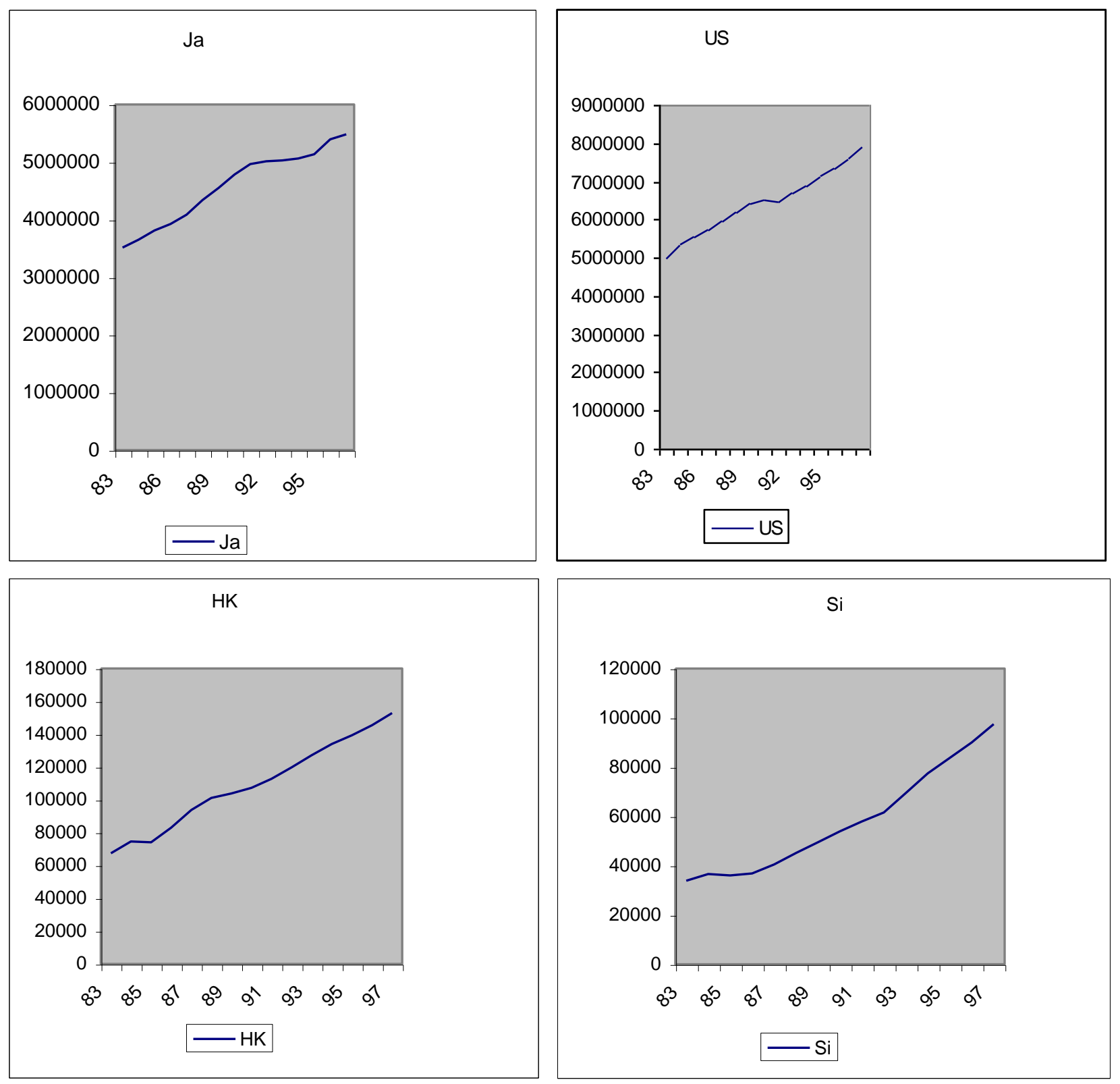

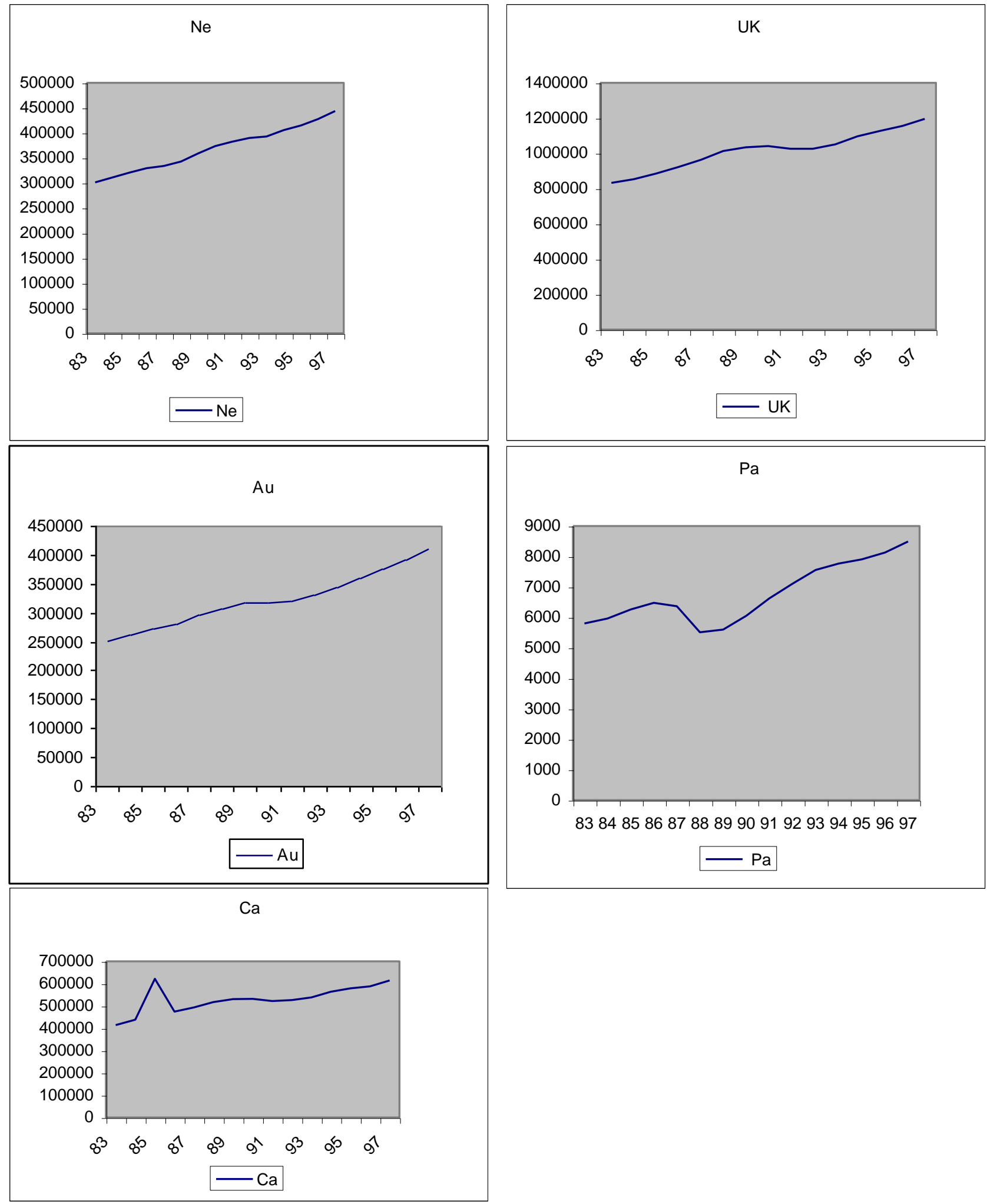

Sources: World Development Distributor (1999\&2000) 